\title{
The role of commercial bovine serum albumin preparations in the culture of one-cell rabbit embryos to blastocysts
}

\author{
M. T. Kane and D. R. Headon* \\ Departments of Physiology and *Biochemistry, University College, Galway, Ireland
}

\begin{abstract}
Summary. Normal bovine serum albumin (BSA) in a complete medium without energy substrates promoted growth of 1-cell embryos to hatched blastocysts. Defatted charcoal-treated BSA did not promote growth to the blastocyst stage but the addition of pyruvate or palmitic and oleic acids allowed blastocyst growth but not blastocyst hatching. Sodium dodecyl sulphate-gel electrophoresis showed that both the normal and defatted BSA samples were heavily contaminated by proteins other than albumin. Fractionation of the normal BSA on Sephadex G-200 indicated that the property of promoting complete blastocyst hatching was not due to the albumin but was associated with the higher mol. wt fraction of the BSA. Extraction of normal BSA with chloroform appeared to destroy the hatching-promoting ability as neither the residue after extraction nor defatted BSA to which the organic extractate had been added promoted complete blastocyst hatching. It is concluded that commercial BSA may have at least two effects on blastocyst growth: (1) energy provision via albumin-bound fatty acids, and (2) promotion of blastocyst hatching by a non-albumin component.
\end{abstract}

\section{Introduction}

Crystallized bovine serum albumin (BSA) is commonly used as the only macromolecular component in media used for the culture of mouse and rabbit early embryos in vitro. Embryo culture media containing BSA have been called 'defined' media (Whitten \& Biggers, 1968; Kane \& Foote, 1970a) but this statement is clearly incorrect because: (1) a major function of albumin in the blood is to carry smaller molecules especially lipid-soluble substances such as fatty acids and steroid hormones (Fredrickson \& Gordon, 1958; Westphal, 1970); (2) Chen (1966) reported that commercial samples of albumin varied in fatty acid content from 0.06 to $2.5 \mathrm{~mol}$ fatty acid/mol albumin; (3) Kane (1979) found that fatty acids bound to albumin could function as energy sources in supporting growth of 1-cell rabbit embryos to viable morulae; and (4) we have found that commercial BSA is heavily contaminated with other proteins (D. R. Headon \& M. T. Kane, unpublished observations). These findings indicate that the non-albumin components of commercial BSA preparations may be important in media used for culture of early rabbit embryos. The present study investigated the role of these non-albumin components of commercial BSA in promoting growth of 1-cell rabbit embryos to blastocysts. 


\section{Materials and Methods}

\section{Embryos}

New Zealand White and Dutch-Belted does were induced to superovulate and fertilized 1-cell embryos were flushed from the oviducts $20-21 \mathrm{~h}$ after the hCG injection and insemination (Kane \& Buckley, 1977). The flushing medium was a Hepes buffered simple salt solution containing $0.1 \%$ BSA (Kane, 1979). The embryos were then washed free of oviduct fluid with repeated changes of the flushing medium and were placed in culture in $0.5 \mathrm{ml}$ droplets of culture medium under paraffin liquid in tissue culture dishes. Culture dishes were maintained at $38^{\circ} \mathrm{C}$ under a gas phase of $5 \% \mathrm{CO}_{2}$ in air. Embryos were cultured for 5 days and the numbers of early blastocysts (blastocoele just visible), expanding blastocysts (blastocyst beginning to expand and to thin the zona) and hatched blastocysts (zona shed completely) were recorded.

\section{Culture medium}

The basic culture medium contained $108 \mathrm{~mm}-\mathrm{NaCl}, 4.78 \mathrm{~mm}-\mathrm{KCl}, 1.71 \mathrm{~mm}-\mathrm{CaCl}_{2} \cdot 2 \mathrm{H}_{2} \mathrm{O}$, $1 \cdot 19 \mathrm{~mm}-\mathrm{KH}_{2} \mathrm{PO}_{4}, 1 \cdot 19 \mathrm{~mm}-\mathrm{MgSO}_{4} \cdot 7 \mathrm{H}_{2} \mathrm{O}, \mathrm{mm}-\mathrm{NaHCO}_{3}, 100$ units penicillin $\mathrm{G} / \mathrm{ml}, 50 \mu \mathrm{g}$ streptomycin sulphate/ml and the amino acids, vitamins and trace elements of Ham's F10 medium (Ham, 1963; Kane \& Foote, 1970b).

\section{Bovine serum albumin}

In this paper BSA is used to refer to commercial samples of crystallized bovine serum albumin whereas albumin is used for the pure protein. Two types of BSA were used, normal BSA and defatted BSA (Sigma, London). The defatted BSA was produced by removal of the fatty acids and other protein-bound contaminants by charcoal treatment (Chen, 1966) and was stated by the manufacturer to contain $<0.005 \%$ fatty acid. Using the method of Duncombe (1964), we found it to be free of fatty acid and the normal BSA to contain 0.17 mol fatty $\mathrm{acid} / \mathrm{mol}$.

Chloroform extraction of normal BSA. Normal BSA $(0.2 \mathrm{~g})$ to which 1 mol palmitic acid/mol BSA was added was dissolved in $3 \mathrm{ml}$ water. This was vortex-mixed and extracted 3 times with $5 \mathrm{ml}$ chloroform (Analar grade, BDH, Poole, Dorset, England) each time. The residue was then diluted to about $30 \mathrm{ml}$ with water and about $20 \mathrm{ml}$ chloroform were added. The chloroform was then evaporated in a rotary evaporator and the sample freeze-dried twice.

The chloroform containing the extractate of normal BSA was added to $0.1 \mathrm{~g}$ defatted BSA (containing $1 \mathrm{~mol}$ palmitic acid added/mol BSA) dissolved in $30 \mathrm{ml}$ water. The chloroform was then evaporated with a rotary evaporator and freeze-dried twice as for the normal BSA residue. The water used in this and in all other experiments was purified by single distillation in glass followed by carbon filtration, deionization and membrane filtration (Milli-Q-system: Millipore, London). The palmitic acid was added to the BSA samples to minimize protein denaturation and samples were freeze-dried twice to remove all traces of chloroform.

Fractionation of $B S A$. Both normal and defatted BSA samples were fractionated on a Sephadex G-200 column $(27 \times 2.5 \mathrm{~cm})$. The eluent was $10 \mathrm{~mm}$-ammonium bicarbonate $(\mathrm{pH}$ 7.4), the flow rate was $12 \mathrm{ml} / \mathrm{h}$ and fractions were collected in volumes of $3.5 \mathrm{ml}$ by drop counting. Protein recoveries were checked in all experiments and were within the range 95.5-102.5\%. Protein concentration was determined by the method of Warburg \& Christian (1941). Fractions of the column eluent were pooled as indicated in Text-fig. 1 (i.e. regions A and $\mathbf{B}$ of elution profiles) and then freeze-dried. Before freeze-drying all samples were diluted to identical protein concentrations. Unfractionated samples were diluted with $10 \mathrm{~mm}$-ammonium bicarbonate to similar protein concentration and also freeze-dried. 


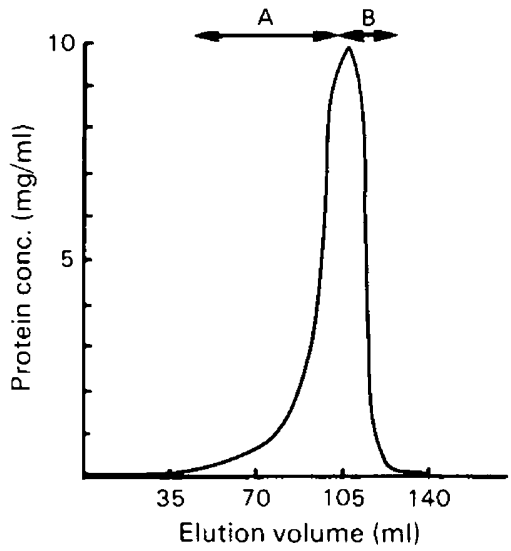

Text-fig. 1. Elution profile of normal BSA from a column of Sephadex G-200. Fractions A and B were pooled as indicated by the arrows. Defatted BSA exhibited an almost identical elution profile and provided similar A and B fractions.

The protein purity of the unfractionated normal and defatted BSA and their A and B fractions was determined by sodium dodecyl sulphate (SDS)-polyacrylamide gel electrophoresis carried out in 6-27\% polyacrylamide gel gradients. Samples for electrophoresis were dissolved at a concentration of $3 \mathrm{mg} / \mathrm{ml}$ in a medium containing $0.6 \%(\mathrm{w} / \mathrm{v})$ SDS, 40 mM-2-mercaptoethanol and $10 \%(\mathrm{w} / \mathrm{v})$ sucrose in a buffer of $88.7 \mathrm{mM}$-Tris- $2.5 \mathrm{~mm}$-disodium EDTA-81.5 mM-boric acid ( $\mathrm{pH} \mathrm{8.3).} \mathrm{SDS} \mathrm{and} \mathrm{mercaptoethanol} \mathrm{were} \mathrm{used} \mathrm{to} \mathrm{ensure} \mathrm{that} \mathrm{all} \mathrm{of}$ the albumin and other proteins were present in monomeric form (Gordon, 1975). Crystallized albumin is normally a monomer but a small proportion exists in dimeric and higher polymeric forms (Peters, 1975). Pyronin Y $(100 \mu \mathrm{g} / \mathrm{ml})$ was used as a tracker dye. The samples were heated at $100^{\circ} \mathrm{C}$ for $5 \mathrm{~min}$. All electrophoretic separations were carried out using the Uniscil Gradipore System. Samples of $40 \mu \mathrm{g}$ were applied to the gel using sample applicators. The gels were run at $75 \mathrm{~V}$ and at $\mathrm{pH} 8.3$ in the Tris-EDTA-boric acid buffer containing $0.1 \%(\mathrm{w} / \mathrm{v})$ SDS. The electrophoresis was terminated when the tracker dye reached the bottom of the gel, a period of approximately $3 \mathrm{~h}$. The gels were fixed and stained as described by Fairbanks, Steck \& Wallach (1971). Gels were stained with amido black, and densitometer recordings were made to determine the protein content of the various bands.

Adjustment of fatty acid level of BSA. BSA with a concentration of $5 \mathrm{~mol}$ palmitic or oleic $\mathrm{acid} / \mathrm{mol}$ was prepared from commercial defatted BSA as described by Kane (1979). This was added to defatted BSA to give the requisite concentration of fatty acid. Palmitic and oleic acids were chosen because these are the fatty acids normally bound to albumin in greater amounts (Fredrickson \& Gordon, 1958) and because palmitic acid is saturated and oleic acid unsaturated.

\section{Statistical considerations}

Embryos collected on one day were pooled and divided among the treatments for that day. The embryos collected on one day constituted one replicate of a randomized complete block experiment. Appropriate statistical comparisons of the overall treatment means were carried out by $\chi^{2}$ test with the Yates correction for continuity.

\section{Experiments}

Experiment 1. The 1-cell embryos were cultured in normal BSA, defatted BSA, defatted BSA plus pyruvate $\left(2 \times 10^{-4} \mathrm{M}\right)$ and defatted BSA containing $1 \mathrm{~mol} \mathrm{palmitic} \mathrm{and} \mathrm{oleic} \mathrm{acid} / \mathrm{mol}$. 
Experiment 2. To test for possible toxic effects of defatted BSA or the fatty acids, the effect of normal BSA was compared with that of normal BSA plus defatted BSA and palmitic and oleic acids.

Experiment 3. Embryos were cultured in unfractionated BSA, both normal and defatted, and in fraction A (high mol. wt) and fraction B (low mol. wt) of both normal and defatted BSA.

Experiment 4 . The possibility that the ability of normal BSA to cause complete blastocyst hatching was chloroform-extractable was examined. Embryos were cultured in normal BSA, defatted BSA, chloroform-extracted normal BSA and defatted BSA plus the chloroform extractate. To eliminate the effect of the fatty acids bound to the normal BSA as energy sources, pyruvate $\left(5 \times 10^{-4} \mathrm{M}\right)$ and glucose $\left(10^{-3} \mathrm{M}\right)$ were included in all treatments.

\section{Results}

\section{Experiment 1}

The results of this experiment (Table 1) showed that defatted albumin supported almost zero growth to the blastocyst stage but the addition of pyruvate or the fatty acids, palmitic and oleic did allow some blastocyst growth. However, embryos in the defatted albumin did not expand very well when compared with embryos in normal BSA and none hatched completely from the zona.

Table 1. Comparison of normal BSA, defatted BSA and defatted BSA supplemented with pyruvate or fatty acids for growth of 1-cell rabbit embryos

\begin{tabular}{lcccc}
\hline & Normal BSA & Defatted BSA & $\begin{array}{c}\text { Defatted BSA } \\
+\end{array}$ & $\begin{array}{c}\text { Defatted BSA } \\
+\end{array}$ \\
pyruvate $\left(2 \times 10^{-4} \mathrm{M}\right)$ & oleic and palmitic acids \\
\hline $\begin{array}{l}\text { No. of embryos } \\
\text { \% Early }\end{array}$ & 51 & 57 & 54 & 55 \\
$\begin{array}{c}\text { blastocysts } \\
\begin{array}{l}\text { Expanding } \\
\text { blastocysts }\end{array}\end{array}$ & 59 & $12^{* * *}$ & $35^{*}$ & 40 \\
$\% \begin{array}{l}\text { Hatched } \\
\text { blastocysts }\end{array}$ & 59 & $5^{* * *}$ & $17^{* * *}$ & $29^{* * *}$ \\
\hline
\end{tabular}

Concentration of BSA was $1.5 \%(0.22 \mathrm{mM})$ in all cases and concentration of oleic and palmitic acids was $1 \mathrm{~mol} / \mathrm{mol}$ BSA. The experiment was replicated 4 times.

Values significantly different from that for normal BSA: ${ }^{*} P<0.05,{ }^{* *} P<0.01,{ }^{* * *} P<0.001$.

\section{Experiment 2}

This experiment (Table 2) shows that neither the defatted BSA nor the palmitic and oleic acids caused a significant decrease of blastocyst formation, expansion or hatching and were therefore not markedly toxic to the ova.

\section{Experiment 3}

The unfractionated samples of both normal and defatted BSA and the A fractions (high mol. wt) of both types of BSA used in this experiment were heavily contaminated with other proteins (Table 3; Text-fig. 2). These were mainly proteins, most probably globulins, with a molecular weight greater than that of albumin. The B fractions contained from $99-100 \%$ albumin. We have tested samples of commercial BSA from three other suppliers and found similar levels of protein contamination (unpublished observations). 
Table 2. Comparison of normal BSA alone and with added defatted BSA and fatty acids for growth of 1-cell rabbit embryos

\begin{tabular}{lcc}
\hline & $\begin{array}{c}\text { Normal BSA (0.9\%) } \\
+ \\
\text { defatted BSA (0.6\%) } \\
+\end{array}$ \\
& $\begin{array}{c}\text { Normal } \\
\text { BSA (1.5\%) }\end{array}$ & $\begin{array}{c}+ \\
\text { oleic and palmitic acids* }\end{array}$ \\
\hline $\begin{array}{l}\text { No. of 1-cell embryos } \\
\text { \% Early blastocysts }\end{array}$ & 36 & 38 \\
\% Expanding & 75 & 68 \\
blastocysts & 72 & 66 \\
\% Hatched blastocysts & 67 & 45 \\
\hline
\end{tabular}

This experiment was replicated 3 times and there were no significant differences between treatments $(P>0.05)$.

* $1 \mathrm{~mol} / \mathrm{mol}$ BSA.

All the defatted albumin samples were unable to support any significant degree of blastocyst growth or blastocyst hatching whereas all the normal albumin samples supported both blastocyst growth and complete hatching (Table 3). However, although the pure albumin fraction $B$ of the normal BSA promoted significantly more blastocyst formation than did the unfractionated BSA or the heavily contaminated fraction A, it gave a lower proportion of hatched blastocysts than either, as shown by expressing the numbers of hatched blastocysts as percentages of the early blastocysts formed (Table 3). Expressed in this manner the contaminated BSA was significantly $(P<0.001)$ better at promoting complete blastocyst hatching.

Table 3. Albumin content of BSA and two fractions from Sephadex G-200 and their effects on rabbit blastocyst growth

\begin{tabular}{lcccccccc}
\hline & \multicolumn{3}{c}{ Normal BSA } & & \multicolumn{3}{c}{ Defatted BSA } \\
\cline { 2 - 3 } \cline { 7 - 9 } & $\begin{array}{c}\text { Original } \\
\text { sample }\end{array}$ & $\begin{array}{c}\text { Fraction } \\
\text { A }\end{array}$ & $\begin{array}{c}\text { Fraction } \\
\text { B }\end{array}$ & & $\begin{array}{c}\text { Original } \\
\text { sample }\end{array}$ & $\begin{array}{c}\text { Fraction } \\
\text { A }\end{array}$ & $\begin{array}{c}\text { Fraction } \\
\text { B }\end{array}$ \\
\hline \% Albumin & 86 & 79 & 100 & 89 & 82 & 99 \\
No. of 1-cell embryos & 74 & 77 & 75 & 41 & 45 & 44 \\
No. of early blastocysts & 32 & 29 & 46 & 0 & 3 & 6 \\
(\%) & $(43)$ & $(38)$ & $(61)^{*}$ & & $(0)^{* * *}$ & $(7) * *$ & $(14)^{* * *}$ \\
No. of hatched blastocysts & 24 & 24 & 14 & & 0 & 0 & 0 \\
As \% of 1-cell stages & 32 & 32 & 19 & & $0^{* * *}$ & $0^{* * *}$ & $0^{* * *}$ \\
As \% of early blastocysts & 75 & 86 & $30^{* * *}$ & - & - & - \\
\hline
\end{tabular}

All BSA levels were $1.5 \%$. The normal BSA treatments were replicated 6 times and the defatted BSA treatments 4 times. Fraction $A$ is the high mol. wt and fraction $B$ the low mol. wt fraction (see Text-fig. 1).

Values significantly different from original sample of normal BSA; ${ }^{*} P<0.05$, ${ }^{* *} P<0.01,{ }^{* * *} P<0.001$.

\section{Experiment 4}

Neither chloroform-extracted BSA, nor defatted BSA reconstituted with the chloroform extractate nor a mixture of both of these allowed any significant proportion of complete blastocyst hatching (Table 4), indicating that the chloroform extraction procedure destroyed the factor in the normal BSA that promoted hatching. 


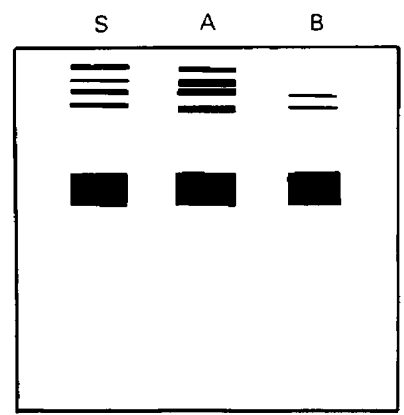

$\oplus$

$\Theta$

Text-fig. 2. SDS gradient gels stained with amido black after electrophoresis of unfractionated normal BSA (S), and the high (A) and low (B) molecular weight fractions of normal BSA from a Sephadex G-200 column. Defatted BSA and its A and B fractions produced a similar pattern.

Table 4. Effect of extraction of normal BSA with chloroform and reconstitution of defatted BSA with the extractate on blastocyst growth

\begin{tabular}{lccccc}
\hline & & & & & $\begin{array}{c}\text { Chloroform- } \\
\text { extracted BSA } \\
+\end{array}$ \\
& $\begin{array}{c}\text { Normal } \\
\text { BSA }\end{array}$ & $\begin{array}{c}\text { Chloroform- } \\
\text { extracted } \\
\text { BSA }\end{array}$ & $\begin{array}{c}\text { Defatted } \\
\text { BSA }\end{array}$ & $\begin{array}{c}\text { Defatted BSA } \\
+ \\
\text { extractate }\end{array}$ & $\begin{array}{c}\text { defatted BSA } \\
+ \\
\text { extractate }\end{array}$ \\
\hline $\begin{array}{l}\text { No. of 1-cell embryos } \\
\text { \% Early blastocysts }\end{array}$ & 31 & 31 & 30 & 31 & 30 \\
\% Expanding blastocysts & 87 & 74 & 77 & 100 & 73 \\
\% Hatched blastocysts & 71 & 63 & 63 & 97 & 70 \\
\hline
\end{tabular}

This experiment was replicated 3 times.

Values significantly different from those for normal BSA, ${ }^{*} P<0.001$.

\section{Discussion}

These experiments demonstrate two clear-cut effects of commercial BSA samples on the growth of rabbit 1-cell embryos to blastocysts in culture. The first effect is the promotion of growth from the 1-cell stage to the blastocyst in the absence of added energy substrates. This effect would appear to be due to the presence of fatty acids bound to the BSA which can provide energy for growth of 1-cell rabbit embryos. This function can be replaced in the charcoal-treated defatted BSA by replacing some fatty acid or by providing another energy source such as pyruvate (Table 1). The ability of long-chain fatty acids and, to a lesser extent, short-chain acids to provide energy for growth of 1-cell rabbit embryos to viable morulae has already been demonstrated (Kane, 1979). The very high proportion of blastocysts developing in the defatted BSA containing $5 \times 10^{-4} \mathrm{M}$-pyruvate and $10^{-3} \mathrm{M}$-glucose (Exp. 4) as compared with the response in $2 \times 10^{-4} \mathrm{M}$-pyruvate without glucose (Exp. 1) indicates that the former combination of energy substrates is more suitable in the presence of defatted BSA. Statistical comparison of these two treatments is not, however, valid because two different experiments are involved. A factor that may affect the optimum level of energy substrate to use in the presence of defatted BSA as compared with normal BSA is that defatted BSA may more readily bind energy substrates.

The second effect of BSA is the promotion of complete zona shedding or hatching by the rabbit blastocyst associated with an increase in blastocyst growth and expansion. This effect appeared to be markedly reduced when the BSA was purified to an albumin content of about $100 \%$ (Table 3) on Sephadex G-200. Only 30\% of the blastocysts formed in the presence of the

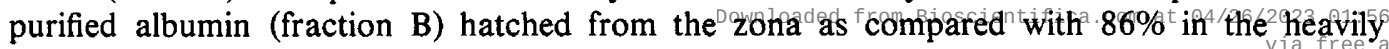


contaminated fraction A. This suggests that the factor promoting complete hatching is either a high molecular weight protein or some molecule bound to a high molecular weight protein. The charcoal defatting treatment not only removes fatty acids but also binds certain small molecules, peptides and proteins (Chen, 1966). This suggestion is strengthened by the finding that chloroform extraction destroyed the ability of the BSA to promote complete blastocyst hatching without significantly decreasing growth to the blastocyst stage.

Another interesting point to emerge from the experiment with the G-200-fractionated material was that the purified albumin resulted in a significantly greater proportion of blastocysts than did the unfractionated BSA even though a smaller proportion of these blastocysts then hatched completely. This indicates that while normal commercial BSA contains a factor that promotes blastocyst hatching, it also contains factors that are toxic to the embryos.

The electrophoresis data emphasize that commercial samples of BSA are highly contaminated with other proteins. Protein contamination of commercial BSA samples has been already documented (Peters, 1975). This fact plus the information in the literature on the binding of low molecular weight compounds to albumin indicate that commercial BSA is an heterogeneous and ill-defined product. Variation in these contaminants may explain the variation in the ability of different samples of normal, i.e. non-defatted, BSA to cause complete blastocyst hatching (unpublished observations).

Hatching of rabbit blastocysts does not take place in vivo and the fact that it does take place in vitro has been suggested as being due to the almost complete absence of the mucin coat on the 1-cell embryos used in this type of study (Kane, 1975). In vivo the zona and mucin coat are thinned by the enormous expansion of the blastocyst. Knowledge of the hatching-promoting factor in normal BSA should provide some indication as to whether hatching in vitro is promoted by weakening of the zona or by a general growth-promoting effect on the blastocyst or by a combination of both processes.

This work was supported by a grant to M.T.K. from An Foras Taluntais. Thanks are due to Miss Marian Roche and Mrs Patricia Commins for technical assistance.

\section{References}

Chen, R.F. (1966) Removal of fatty acids from serum albumin by charcoal treatment. J. biol. Chem. 242, $173-181$.

Duncombe, W.G. (1964) The colorimetric micro-determination of non-esterified fatty acids in plasma. Clin. Chim. Acta 9, 122-125.

Fairbanks, G., Steck, T. \& Wallach, D.F.H. (1971) Electrophoretic analysis of the major polypeptides of the human erythrocyte membrane. Biochemistry, N.Y. 10, 2606-2617.

Fredrickson, D.S. \& Gordon, R.S., Jr (1958) Transport of fatty acids. Physiol. Rev. 38, 585-630.

Gordon, A.H. (1975) Electrophoresis of Proteins in Polyacrylamide and Starch Gels. North Holland Publishing Co., Amsterdam.

Ham, R.G. (1963) An improved nutrient solution for diploid Chinese hamster and human cell lines. Expl Cell Res. 29, 515-526.

Kane, M.T. (1975) Inhibition of zona shedding of rabbit blastocysts in culture by the presence of a mucin coat. J. Reprod. Fert. 44, 539-542.

Kane, M.T. (1979) Fatty acids as energy sources for culture of one-cell rabbit ova to viable morulae. Biol. Reprod. 20, 323-333.
Kane, M.T. \& Buckley, N.J. (1977) The effects of inhibitors of energy metabolism on the growth of one-cell rabbit ova to blastocysts in vitro. J. Reprod. Fert. 49, 261-266.

Kane, M.T. \& Foote, R.H. (1970a) Fractionated serum dialysate and synthetic media for culturing 2-and4-cell rabbit embryos. Biol. Reprod. 2, 356-362.

Kane, M.T. \& Foote, R.H. (1970b) Culture of two- and four-cell rabbit embryos to the expanding blastocyst stage in synthetic media. Proc. Soc. exp. Biol. Med. 133, 921-925.

Peters, T. (1975) Serum albumin. In The Plasma Proteins, Vol. 1, pp. 133-181. Ed. C. F. Putman. Academic Press, New York.

Warburg, O. \& Christian, W. (1941) Isolierung und Kristallisation des Garungferments Enolase. Biochem. Z. 310, 384-401.

Westphal, W. (1970) Corticosteroid-binding globulin and other steroid hormone carriers in the blood stream. $J$. Reprod. Fert., Suppl. 10, 15-38.

Whitten, W.K. \& Biggers, J.D. (1968) Complete development in vitro of the pre-implantational stages of the mouse in a simple chemically defined medium. J. Reprod. Fert. 17, 399-401. 